Journal of Agriculture and Food Sciences

Volume 19 Number 1, April 2021 pp 48- 62

Esiegwu, A. C. and Obih, T.K.O

\title{
GROWTH PERFORMANCE, HAEMATOLOGICAL AND SERUM BIOCHEMICAL INDICES OF BROILER STARTER CHICKENS OFFERED DIETARY SUPPLEMENT OF COMFREY LEAVES EXTRACT
}

\author{
Esiegwu, A. C. and Obih, T.K.O \\ Department of Animal Science and Fisheries, Imo State University, Owerri. \\ E-mail:arthuresiegwu@yahoo.com
}

\begin{abstract}
An experiment was conducted to determine the effect of nutritional supplement of comfrey symphytum leaves extract on the performance, haematological and serum biochemical indices of starter broilers. $200 \mathrm{~g}$ of Comfrey symphytum leaves were squeezed in 1 litre of $\mathrm{H}_{2} \mathrm{O}$ with a juicer to produce Comfrey symphytum extract. The leaves extract was further mixed (diluted) in clean drinking water at the rate of $\mathrm{Oml} / \mathrm{l}$ of $\mathrm{H}_{2} \mathrm{O}, 25 \mathrm{ml} / \mathrm{l}$ of $\mathrm{H}_{2} \mathrm{O}$, 50ml/l of $\mathrm{H}_{2} \mathrm{O}$ and $75 \mathrm{ml} / \mathrm{l}$ of $\mathrm{H}_{2} \mathrm{O}$ designated as $T_{1}, T_{3}, T_{4}$ and $T_{5} . T_{2}$ was given conventional supplement (divertamin). Five groups of 30-day old chicks of Agritech breed were randomly assigned to one of the supplementary Comfrey symphytum leaves extract and the divertamin supplement for 28days. Each was subdivided into three replicates of 10 chicks each. The broiler chicks were fed normal broiler starter ration for all the groups. At the end of the 28days trial, performance indices result showed that mean final weight, mean weight changes, mean daily weight gain, mean daily feed intake and feed conversion ratio were not significantly affected $(P>0.05)$. However, $T_{4}(50 \mathrm{ml}$ per litre of $\left.\mathrm{H}_{2} \mathrm{O}\right)$ and $\mathrm{T}_{5}\left(75 \mathrm{ml} /\right.$ litre of $\left.\mathrm{H}_{2} \mathrm{O}\right)$ gave better performance in terms of feed conversion ratio. The cost/kg of weight gain was cheaper at $T_{4}$ and $T_{5}$. All the haematological (Haemoglobin, packed cell volume, red blood cell and white blood cell) and serum biochemical indices (total protein, urea, creatinine, cholesterol and liver enzymes) did not show any significant treatment effect $(P>0.05)$. It was concluded that Comfrey symphytum had no deleterious effect on starter broilers and its use as a nutritional supplement could improve performance at 50 - $75 \mathrm{ml} / \mathrm{l}$ of $\mathrm{H}_{2} \mathrm{O}$ and reduce cost/kg of weight gain.
\end{abstract}

Key words: Comfrey leaves, Extract, Performance, Haematology, Biochemistry.

https://dx.doi.org/10.4314/jafs.v19i1.4

\section{INTRODUCTION}

The need to improve on the growth and liveability of broilers is becoming very urgent due to the need to produce healthy table meat within a short period of time for the increasing global population (Esiegwu 2019). FAO (2010) reported that out of the 53g of protein per caput per day, Nigeria obtains 10 - 15g per caput per day from animal sources as against the recommended $35 \mathrm{~g}$ per caput per day. This challenge is as a result of limited production of animal products due to high cost of production which affects the final consumers in the form of high price of animal 
Journal of Agriculture and Food Sciences

Volume 19 Number 1, April 2021 pp 31- 47

Esiegwu, A. C. and Obih, T.K.O and poultry products leading to a drop in demand and consumption. Most poultry feed may not be nutritionally adequate due to lack of essential nutrients necessary for growth and good health. The implication is the purchase of exorbitant synthetic nutrients fortified with vitamins, minerals and some essential amino acids to enhance the nutritional status of the animals which adds to the cost of production and consequently, high cost of broiler meat (Esiegwu, 2019). Protein from plant leaves source is perhaps the most naturally abundant and the cheapest potential source of protein (Fasuyi and Nonyerem, 2007). Leaf vegetables supply minerals, proteins and vitamins which could complement the inadequacies of most feed stuffs (Hon and Basir, 1980). It is necessary to exploit the benefits of most of these vegetables as nutritional supplement in order to reduce the cost of using conventional supplements that may add heavily to the cost of production. Leaves as a nutritional supplement is good but limited due to high fibre content which is a burden to the digestive system (Gala et al., 2003). A healthy body with sound digestive system has the capacity to disintegrate about $35 \%$ of the ingredients from vegetables and assimilate them where as the body is able to absorb $95 \%$ of substances contained in juice (Gala et al., 2003). From the report above, it is evident that the use of juice extract as a dietary supplement from plant leaves appear to be more effective and efficient way of deriving the nutrients and enzymes in leaves of plants required in the body for proper metabolism and utilization in the tissues for growth and the other metabolic functions.

Comfrey plant leaves appear to have the potential to supply needed proteins, vitamins and minerals and could serve as a nutritional supplement to enhance growth. Comfrey (Symphytum officinale L) is native to Europe, Central Asia and prevalent in the South Eastern part of Nigeria, where it is used in bone healing, treating anaemia and as a blood booster. Greeks and Romans used Comfrey to stop heavy bleeding, treat bronchial problems, heal wounds and broken bones; poultices were made for external wounds and tea was consumed for internal ailments (Teynor $e t$ al., 1992). Comfrey like most green vegetables is deficient in methionine and low in phenylanine (Teynor et al., 1992). Comfrey leaves is very high in crude protein (between 21 to $31 \%$ crude protein) and is a forage of high digestibility (between 37 to 77\%) (Robert, 1983). The fresh leaves of comfrey are eaten by sheep, pigs and poultry but are often not palatable for cattle and rabbits (Robert, 1983). Cattle and rabbits enjoy leaves when the forage is wilted or ensiled. The forage is also fed to horses, goats, chinchillas and caged birds. Robert (1983) also reported that comfrey contains 18 amino acids - Glutamic acid, (12.49\%); Leucine, (10.04\%); Aspartic acid, 
Journal of Agriculture and Food Sciences

Volume 19 Number 1, April 2021 pp 48-62

Esiegwu, A. C. and Obih,

(9.34\%); Valine, (7.02\%); Arginine, (6.37\%); Phenylanine, (6.34\%); Alanine, (5.79\%); Proline, (5.45\%); Glycine, (5.37\%); Isoleucine, (5.31\%); Lysine, (5.21\%); Cystine, (4.67\%); Threonine, (4.51\%); Tyrosine, (3.74\%); Serine, (2.96\%); Methionine, (2.46\%); Histidine, (2.02\%); Tryptophan, (0.91\%). The comfrey is particularly high in $\mathrm{K}$ and is higher than many other forage crops in $\mathrm{Ca}, \mathrm{P}, \mathrm{Fe}$ and $\mathrm{Cu}$ (Robert, 1983). It is also rich in minerals such as Potassium, (5.86\%); Nitrogen, (3.53\%); Calcium, (1.44\%); Phosphorus, (0.50\%); Magnesium, (0.30\%); Aluminium, (385parts/million); Iron, (364parts/million); Manganese, (116parts/million); Sodium, (70 parts/million); Zinc, (45parts/million); Nickel, (2parts/million); Chromium, (1part/million); Cadmium, (<1part/million). Despite the nutritional benefits of comfrey, it has toxic or antinutritional factors such as pyrrolizidine alkaloids (which is carcinogenic) and allantoin. Huxtable et al. (1986) cited cases of hepatic veno-occlusive disease that were produced by using pyrrolizidine alkaloid capsules in USA. Comfrey has been reported to cause liver damage and cancerous tumours in rats (Teynor et al., 1992). Alkaloids extracted from Quaker comfrey leaves and injected in rats at dosage of 9 - 71 mg of alkaloid/kg body weight three times per week for several weeks caused liver damage or death (Culvenor et al., 1980). Allantoin chemical stimulates cell production and promotes wound healing. The allantoin $\left(\mathrm{C}_{4} \mathrm{H}_{6} \mathrm{~N}_{4} \mathrm{O}_{3}\right)$ concentration in comfrey particularly the root has led to its extensive use in natural and folk medicine for promoting healings of wounds, ulcers, broken bones, swellings and burns (Hills, 1976). In Nigeria, families and herbal doctors are still harnessing the benefits of comfrey leaf for treatment of various ailments, and as a rich source of vegetable and blood tonic. There is dearth of information on the nutritional and health benefit of comfrey leaves and its potential toxic risks on livestocks and poultry in Nigeria. This research is basically to explore the rich nutritional value of comfrey leaves extract on broiler starter chicken performance and its effect on some blood indices. Therefore, the aim of this research is to investigate the effect of comfrey leaf extract on the growth performance, haematological and serum biochemical indices of starter broiler chickens.

\section{MATERIALS AND METHOD}

\section{Experimental site}

This experiment was carried out at the poultry unit of Teaching and Research farm, Imo State University, Owerri, which is located within the Southern-Eastern agro ecological zone of 
Nigeria. Owerri lies between latitude $5^{0} 29^{\prime}$ North and longitude $7^{0} 20^{\prime}$ East. It is about $91 \mathrm{~m}$ above sea level with annual rainfall, temperature and humidity ranging from $1,500 \mathrm{~mm}$ to $2,200 \mathrm{~mm}$, $20.0-27.5^{\circ} \mathrm{c}$ and $75-90 \%$ respectively (Accuweather, 2015).

\section{Source and processing of comfrey leaf extract}

The comfrey plant was planted in Imo State University teaching and research farm, Owerri. 200g of the leaves were squeezed in 1 litre of water with a juicer to produce comfrey leaves extract. The comfrey leaves extract was mixed in drinking water at the rate of $0 \mathrm{ml} / \mathrm{litre}$ of $\mathrm{H}_{2} \mathrm{O}, 25 \mathrm{ml}$ of extract/litre of $\mathrm{H}_{2} \mathrm{O}, 50 \mathrm{ml}$ of extract/litre of $\mathrm{H}_{2} \mathrm{O}$ and $75 \mathrm{ml}$ of extract/litre of $\mathrm{H}_{2} \mathrm{O}$. Initially, the comfrey leaf meal was dried and sent to the laboratory for proximate, phytochemical and mineral analysis according to AOAC (2010).

\section{Experimental diets}

The birds were fed normal broiler starter diet containing $23 \%$ crude protein and $2600 \mathrm{kcal} / \mathrm{kg}$ of energy as shown in Tables $1 . \mathrm{T}_{1}$ was the control and contained no comfrey leaves extract. $\mathrm{T}_{2}$ contained conventional supplement (Divertamin) and used at the factory recommended level (4g to 4 litres of water). $\mathrm{T}_{3}, \mathrm{~T}_{4}$ and $\mathrm{T}_{5}$ contained $25 \mathrm{ml}$ comfrey leaves extract/litre of $\mathrm{H}_{2} \mathrm{O}, 50 \mathrm{ml}$ of comfrey leaves extract/litre of $\mathrm{H}_{2} \mathrm{O}$ and $75 \mathrm{ml}$ of comfrey leaves extract/litre of water, respectively. The divertamin used contained Vitamin A, 375000 IU; Vitamin $\mathrm{D}_{3}, 110000 \mathrm{IU}$; Vitamin E, 1000 IU; Vitamin K3, 4350 mg; Vitamin B2, 4350 mg; Vitamin B 62350 mg; Vitamin B 12,1350 mg; Vitamin C, 10000 mg; Nicotinic acid, 16700 mg; DL-Methionine, 10000 mg; Llysine, $15000 \mathrm{mg}$; Potassium chloride, $87000 \mathrm{mg}$; Manganese sulphate, $12000 \mathrm{mg}$; Sodium sulphate, 212000 mg; Sodium Chloride, 50000 mg; Copper sulphate, 12000 mg; Zinc sulphate, $12000 \mathrm{mg}$. It is used in poultry to achieve optimum growth and production in the management of stress related to high temperature etc. It is indicated in the treatment of vitamin and mineral deficiency and in the management of stressful condition.

\section{Experimental birds and design}

One fifty (150) day old Agritech broiler chicks were purchased from a certified poultry vendor in Owerri. The chicks were placed together in the brooding pen for three days to stabilize them. Thereafter, the birds were divided into five groups of 30 chicks each in a completely randomized design. Each group was further divided into three replicates of 10 chicks each. Each of the 
Journal of Agriculture and Food Sciences

Volume 19 Number 1, April 2021 pp 48- 62

Esiegwu, A. C. and Obih, T.K.O. groups were assigned to one of the comfrey leaves extract. All the treatment groups were fed same normal broiler starter diet. The initial live weights of the chicks were measured and weekly thereafter. The chicks were fed ad libitum. The chicks in each treatment were served three (3) litres of the comfrey leaves extract mixture per day for the comfrey groups, three (3) litres of the divertamine mixture per day for the divertamin group and normal drinking water for the control. Clean fresh drinking water was supplied to the birds after the consumption of the comfrey leaves extract and the divertamin water. The trial lasted for four weeks.

\section{Data collection}

Feed intake was recorded daily and the birds were weighed weekly after the initial body weights were taken. Feed intake was determined by weighing the feed offered and the left over the next morning. The difference between the two values was the feed consumed. Feed conversion ratio was determined by dividing average daily feed intake by average daily body weight gain.

\section{Haematological and serum biochemical studies}

At the last day of the feeding trial, three birds per treatment were randomly selected to determine their haematological and serum biochemical indices. $3 \mathrm{ml}$ blood samples were collected from the wing vein of the birds using syringe and needle and placed in the specimen bottles with EDTA (Ethylene Diamine Tetra Acetate) for haematological studies. Blood was analysed within three hours of collection for haemoglobin (HB), packed cell volume (PCV), red blood cell (RBC), mean cell volume (MCV), mean cell haemoglobin $(\mathrm{MCH})$, mean cell haemoglobin concentration (MCHC), and white blood cell (WBC) as outlined by Ochie and Kolhatkar (2000). Another 5ml of blood samples were collected and placed in the specimen bottles without EDTA for serum biochemical analysis. Blood samples placed in the specimen bottles without EDTA were used to analyse the serum biochemical parameters such as urea, total protein, creatinine, cholesterol, serum electrolytes and liver enzymes as outlined by Ochie and Kolhatkar (2000).

\section{Statistical analysis}

Data collected were subjected to analysis of variance using the SPSS software (2012). Where analysis of variance indicated significant treatment effects, means were compared using Duncan's New Multiple Range Test (DNMRT) (SPSS, 2012) 
Journal of Agriculture and Food Sciences

Esiegwu, A. C. and Obih, T.K.O

Volume 19 Number 1, April 2021 pp 48-62

\section{RESULTS AND DISCUSSION}

\section{Proximate, mineral and phytochemical composition of comfrey leaf}

Proximate, mineral and phytochemical composition of comfrey leaf is presented in Tables (2). The protein content was close to the values (21\% - 31\%) reported by Robert (1983). It was very high in $\mathrm{Ca}, \mathrm{K}, \mathrm{Na}$ and very rich in $\mathrm{Fe}, \mathrm{Mg}$ and $\mathrm{Zn}$. Robert (1983) reported that comfrey is particularly high in $\mathrm{K}$ and is higher than many other forage crops in $\mathrm{Ca}, \mathrm{P}, \mathrm{Fe}$ and cu. The high values of $\mathrm{Ca}$ and $\mathrm{Mg}$ in this report supports its use in the South Eastern part of Nigeria and the world at large in bone healing. The presence of $\mathrm{Fe}$ and $\mathrm{Cu}$ reveals the reason behind its use in treating anaemia and as a blood booster. $\mathrm{Fe}$ and $\mathrm{Cu}$ is necessary in the formation of haemoglobin. $\mathrm{Cu}$ is a catalyst and not a basic component of haemoglobin. The high content of $\mathrm{K}$ and $\mathrm{Na}$ salt in the leaf will be useful in maintaining the osmotic pressure of the intracellular and extracellular fluid within a narrow range. The leaf also contained phytochemicals or anti nutritional factors such as alkaloid, flavonoid, saponin and tannin which could have chemo-preventive and protective effects or toxic effects depending on the dosage present. Alkaloids extracted from Quaker comfrey leaves and injected in rats at dosage of 9-71 $\mathrm{mg}$ of alkaloid/kg body weight three times per week for several weeks caused liver damage or death (Culvenor et al. 1980). It has also been reported that even in Telfaria occidentalis, the toxicity of the plant is attributed to the alkaloids and saponins present in the roots and leaves (Akubue et al., 1980) while the chemopreventive and protective effects of the plant against free radical scavengers may be due to the presence of high a number of flavonoids and phenolic compounds (Nwanna et al., 2007; Kayode et al., 2010). It is possible that the flavonoids of comfrey leaves may be equally chemopreventive and promotes its use in bone healing and for treatment of other ailments.

\section{Performance of the experimental starter broiler birds offered comfrey leaves extract}

Data on the performance of the experimental birds are presented in Table 3. There was no significant treatment $(\mathrm{P}>0.05)$ effects on the mean weight changes, mean daily weight changes, mean daily feed intake and feed conversion ratio. $\mathrm{T}_{4}\left(50 \mathrm{ml}\right.$ of extract/litre of $\left.\mathrm{H}_{2} \mathrm{O}\right)$ gave the highest mean daily weight gain and lowest feed conversion ratio but not significantly different $(\mathrm{P}>0.05)$ across treatments. The non-significant difference observed in the performance indices may be due to the low dosage of comfrey leaves extract used. Feed cost $/ \mathrm{kg}$ weight gain was best at $\mathrm{T}_{4}\left(50 \mathrm{ml} / \mathrm{litre}\right.$ of extract). $\mathrm{T}_{2}$ (divertamin group) had the highest cost $/ \mathrm{kg}$ weight gain due to 
Journal of Agriculture and Food Sciences

Volume 19 Number 1, April 2021 pp 48-62

Esiegwu, A. C. and Obih, T.K.O

high cost of the supplement and poor feed conversion ratio. It is evident that $\mathrm{T}_{4}$ had better utilization of nutrients than other group and hence, better feed conversion ratio. Low value for feed conversion ratio or efficient feed conversion ratio influences positively lower feed cost $/ \mathrm{kg}$ weight gain. There was no sign of anti-nutritional factor affecting the performance characteristics negatively. The feed conversion ratio was close to the values (2.80 to 2.06) reported by Onu (2012) for starter broilers offered aqueous extract of Telfairia occidentalis leaf extract.

\section{Haematological and serum biochemical indices of broiler starter birds offered comfrey leaves extract}

Data on the haematological and serum biochemical indices of broiler starters offered Comfrey leaves extract are presented in Table 4 and 5. The result of the haematological indices showed that there were no significant $(\mathrm{P}>0.05)$ treatment effects on the haemoglobin $(\mathrm{Hb})$, packed cell volume (PCV), and red blood cell (RBC) across treatments. The values of haemoglobin, Packed cell volume, and red blood cell were within normal reference range (7-13 for $\mathrm{Hb}$; $25-45$ for PCV; 7-12 for RBC) as reported by (Banerjee, 1998; Jain, 1989; Swenson, 1977). Low values for haemoglobin and red blood cell were a good sign of emerging anaemia (Mohammed and Oloyede, 2009). Normal values for haemoglobin, Packed cell volume and red blood cell means adequacy of amino acid and iron metabolism and utilization for heme and normal haemoglobin synthesis. The values of packed cell volume and haemoglobin were within the range 33.50 to 38.00 and 11.00 to 12.75 respectively as reported by Onu (2012) for starter broilers offered aqueous extract of Telfairia occidentalis leaf.

The White blood cell (WBC) and its differentials (Neutrophil, Basophils, Eosinophils, Lymphocytes and Monocytes) were not significantly different $(\mathrm{P}>0.05)$ across treatments. White blood cells were within the normal reference range $9-31 \times 10^{3} / \mathrm{mm}^{3}$ (Banerjee, 1998). White blood cell normally rises in the course of infection or invasion by a foreign body in order to resist it (Esiegwu, 2017). Neutrophils are walls of defence against bacteria in the tissues and their number increases when acute infection is present (Banerjee, 1998). The values obtained which were not significantly different and within normal range was a sign of a healthy animal with intact immune system. Biochemical indices revealed that the liver enzymes, Alkaline phosphatase (ALK), Serum glutamate oxaloacetate transaminase (SGOT), and Serum glutamic pyruvic transaminase (SGPT) did not show any significant difference $(\mathrm{P}>0.05)$ across treatments. 
Journal of Agriculture and Food Sciences

Volume 19 Number 1, April 2021 pp 48-62

Esiegwu, A. C. and Obih, T.K.O

The values for all the treatments were less than the reference values reported by Banerjee (1998). Enzymes were used to check the toxicity of feed to the organs and monitor protein quality. The values were indication of a healthy and intact liver. Low values imply that the liver was not challenged by any toxic factor suggesting normalcy in the activity of the organ. Ologhobo et al. (1993) reported that high value of Alkaline phosphatase in the blood suggests increased activity of the liver due to the presence of toxic factors. Comfrey leaves extract and the divertamin group did not influence negatively the liver, instead there was improved liver function.

Serum urea, creatinine and total protein did not show any significant treatment effect $(P>0.05)$. Total protein, albumin and globulin were not affected by treatments. The dietary supplements of divertamin and Comfrey leaf extract did not affect the treatments negatively $(\mathrm{P}>0.05)$. The nonsignificant difference implies non- interference in amino acids, vitamin and mineral metabolism. Nutrient intake was efficient in both the divertamin and comfrey leaf extract group. The values obtained for the protein were within the normal reference values $5-7 \mathrm{~g} / \mathrm{dl}$ reported by Banerjee (1998). The non-significant difference implies that none of the anti-nutritional factors in comfrey leaf impacted negatively on the protein metabolism. The level administered to the chicks were within safety and tolerable limits. Serum creatinine was similar statistically $(\mathrm{P}>0.05)$ across treatments. Creatinine is also an index to assess the protein value of the body. It was reported that high blood creatinine leads to muscle wastage and weight loss (Ross et al., 1978). Ogunbode et al. (2016) reported that increase in blood creatinine could be as a result of excess breakdown of blood proteins. The values of creatinine in this study and its non-significance $(\mathrm{P}>0.05)$ across treatments imply improved blood proteins and no muscle wastage. Serum urea was similar statistically $(\mathrm{P}>0.05)$. It is one of the indices used to measure protein quality. It has been reported that high level of urea indicates low protein quality (Nworgu et al., 2007). The values of urea and its non- significant difference showed effective amino acid metabolism across treatment. The divertamin and comfrey group were adequate in supplying amino acid nutrient to the birds for improved performance. There was no sign of negative effect on the blood of the birds as a result of the anti-nutrients in the comfrey leaf extracts. Serum cholesterol was statistically the same across treatments. This was an indication of proper fat metabolism and utilization by the tissues. Bush (1991) reported that low level of cholesterol was an indication of fat mal-absorption in the body and the blood. The findings in this study suggests proper metabolism of fat. The divertamin 
Journal of Agriculture and Food Sciences

Esiegwu, A. C. and Obih, T.K.O.

Volume 19 Number 1, April 2021 pp 48-62

and comfrey group were comparable to the control and hence could be inferred that there was no interference in fat metabolism.

\section{CONCLUSION}

The results of the trial have shown that the use of comfrey leaves extract as a nutritional supplement in place of conventional supplements (divertamin) in broiler starter birds was beneficial in improving performance at $50 \mathrm{ml}$ and $75 \mathrm{ml}$ extract per litre of water without any deleterious effect on performance. It also reduced the cost per kg weight gain. The study also revealed that comfrey leaves extract had no deleterious or toxic effect on haematological and serum biochemical indices of starter broiler birds. It was therefore concluded that $50-75 \mathrm{ml}$ of extract per litre of $\mathrm{H}_{2} \mathrm{O}$ gave improved performance and should be used for oral supplementation on broiler starter diet. 
Journal of Agriculture and Food Sciences

Volume 19 Number 1, April 2021 pp 48- 62

Esiegwu, A. C. and Obih, T.K.O.

\section{REFERENCES}

Accuweather (2015). Weather for Owerri, Nigeria. Available at http://www.accuweather.com/en/ng/owerri/253317/weather-forecast/253317. Retrieved November 15, 2015.

Akubue, P., Kar, A., Nnacheta, F. (1980). Toxicity of extracts of roots and leaves of Telfairia occidentalis. Planta Medica, 38(4): 339 - 343. https://doi.org/10.1055/s-2008-1074886

AOAC (2010). Official methods of analysis.19thedition. Association of official Analytical chemists. Washington D. C. USA.

Banerjee, G.C. (1998). A textbook of animal husbandry. 8th edition, Oxford and IBH Publishing Ltd. Pp.118-143.

Bush, B. M. (1991). Interpretation of laboratory results for small animal clinicians. Black well scientific publications. London, United Kingdom. pp.32 67

Culvenor, C. C. J., Clark, M., Edgar, J. A., Frahn, J. L., Jago, M. V., Peterson, J. E. and Smith, L. W. (1980). Structure and toxicity of the alkaloids of Russian comfrey (Symphytum $x$ uplandilum Nyman), a medicinal herb and item of human diet. Experientia, 36: 377-379. https://doi.org/10.1007/BF01975096

Esiegwu, A. C. (2017). Effect of fermented sorghum seed meal on the performance, carcass characteristics and blood profile of broiler finisher chicken. Nigerian Journal of Animal Production, 44(3): 300 - 308. https://doi.org/10.51791/njap.v44i3.650

Esiegwu, A. C. (2019). The supplementary effect of moringa oleifera leaf water on performance and blood indices of finisher broilers. Direct Research Journal of Veterinary Medicine and Animal Science, 4: 27-32.

F.A.O. (2010). The state of food insecurity in the world. Annual report. P62.

Fasuyi, A. O. and Nonyerem, A. D (2007). Biochemical, nutritional and haematological implications of Telfaria occidentalis leaf meal as protein supplement in broiler starter diet. African Journal of biotechnology, 6 (8); 1055-1063. 
Journal of Agriculture and Food Sciences

Volume 19 Number 1, April 2021 pp 48- 62

Gala, D.R., Gala, D. and Gala, S. (2003). Juice-Diet for perfect health. Navneet publication (India) limited., Dantali, Gujarat.

Hills, L. D. (1976). Comfrey Fodder, food and remedy. Universe books, Ny. Pp 253.

Hon, E. T. and Basir, O. (1980). The nutritive value of some Nigerian leafy vegetables, particularly vitamin and mineral contents". Food chemistry, 4; 263-267. https://doi.org/10.1016/0308-8146(79)90014-1

Huxtable, R. J., Luthy, J. and Zweifel, U. (1986). Toxicity of comfrey-pepsin preparations. New Eng. Journal of Med. 315(17):1095. https://doi.org/10.1056/NEJM198610233151715

Jain, N.C. (1989). Veterinary Haematology. 4th edition, Lea and Febiger, Philadelphia, USA.

Kayode, A.A.A., Kayode, O.T., Odetola, A. A. (2010). Telfairia occidentalis ameliorates oxidative brain damage in malnourished rats. International Journal of Biological Chemistry, 4: 10 - 18. https://doi.org/10.3923/ijbc.2010.10.18

Mohammed, N.O and Oloyede, O.B. (2009). Growth performance of broiler chicks fed Aspergillius niger-fermented Terminalia catappa seed meal based diets. Global Journal of Biotechnology and Biochemistry 4(2): 179 183. https://doi.org/10.4314/ijbcs.v4i1.54236

Nwanna, E. Oboh, G. (2007). Antioxidant and hepatoprotective properties of polyphenol extracts from Telfairia occidentalis (Fluted pumpkin) leaves on acetaminophen induced liver damage. Pakistan Journal of Biological Sciences, 10(16): 2682 - 2687. https://doi.org/10.3923/pjbs.2007.2682.2687

Nworgu, F. C., Ogungbenro, S. A. and Solesi, K. S. (2007). Performance and some blood indices of broiler chicken served fluted pumpkin (Telfairia occidentalis) leaves extract supplement. American-Eurasion Journal of Agriculture and Environmental. 2(1): 9098.

Ochie, J. and Kolhatkar, A. (2000). Medical laboratory science. Theory and practice. Tata McGraw-Hill company limited New Delhi.

Ogunbode, A. A, Okeniyi, G., Fatola, O. S. G., Ogunjimi, B. A., and Folarin, M. O. (2016). Haematology and serum indices of wesher pigs fed raw pride of Barbados (Caesalpina pulcherrima) seed meal. Nigerian Journal of Animal Science, 18(2):408 416 
Journal of Agriculture and Food Sciences

Volume 19 Number 1, April 2021 pp 48- 62

Esiegwu, A. C. and Obih, T.K.O

Ologhobo, A.D., Apata, A., Oyejide, A. and Akinpelu, R.O. (1993). Toxixity of raw lima beans (Phaseolus linatus) and lima beans fractions for growing chicks. British Poultry Science, 34: 505-522. https://doi.org/10.1080/00071669308417606

Onu P. N. (2012). Effect of Aqueous Extract of Telfairia occidentalis Leaf on the Performance and Haematological Indices of Starter Broilers. International Scholarly Research Notices, 1-4. //doi.org/10.5402/2012/726515

Robert, G. R. (1983). Comfrey-A controversial crop. Minnesota Report, Item No. AD-MR-2210. Agricultural Experiment Station University of Minnesota MR-191.

Ross, J.G., Halliday, W.G. and Jones, R.M. (1978). Haematological and blood chemistry comparison values for clinical pathology. Poultry Veterinary Records, 102:29-39. https://doi.org/10.1136/vr.102.2.29

SPSS (2012). Statistical package for social sciences, version 21. USA IBM Corporation.

Swenson, M. J. (1977). Dukes' physiology of domestic animals. 9th edition CBS publishers Pvt Ltd. India pp 14-35.

Teynor, T. M., Putnam, D. H., Doll, D. J., Kelling, K. A., Oelka, E. A., Undersander, D. J. and Oplinger, E. S. (1992). Comfrey: Alternative field crops manual. https://hort.purdue.edu 
Journal of Agriculture and Food Sciences

Esiegwu, A. C. and Obih, T.K.O.

60

Volume 19 Number 1, April 2021 pp 48- 62

APPENDICES

Table 1: Ingredient and calculated nutrient composition of experimental broiler starter diet

\begin{tabular}{ll}
\hline Ingredient & Composition $(\% \mathrm{DM})$ \\
\hline Maize & 47.00 \\
Soya bean & 33.00 \\
Fish meal & 3.00 \\
Palm kernel cake & 8.00 \\
Wheat offal & 5.00 \\
Bone meal & 3.00 \\
Salt & 0.25 \\
Vitamin premix & 0.25 \\
Lysine & 0.25 \\
Methionine & 0.25 \\
Calculated Chemical Composition & \\
Crude protein $(\%)$ & 23 \\
ME kcal/kg & 2663.06 \\
Ca $(\%)$ & 1.25 \\
P $(\%)$ & 1.02 \\
Lysine $(\%)$ & 1.48 \\
Methionine $(\%)$ & 0.66 \\
\hline
\end{tabular}

Table 2: Proximate, mineral and phytochemical composition of comfrey leaves

\begin{tabular}{ll}
\hline PARAMETERS & QUANTITY $(\% \mathbf{D m})$ \\
\hline Moisture & 9.90 \\
Ash & 6.90 \\
Protein & 18.37 \\
Ether extract & 5.25 \\
Fibber & 47.12 \\
Nitrogen free extract & 11.87 \\
MINERALS & (Mg/Kg) \\
Cu & 47.85 \\
Zn & 374.20 \\
Mn & 41.85 \\
Fe & 349.65 \\
Ca & 3242.20 \\
Mg & 262.80 \\
Na & 2433.40 \\
K & 2568.50 \\
PHYTOCHEMICALS & \\
Alkaloid (\% DM) & 5.40 \\
Flavonoid (\% DM) & 18.36 \\
Saponin (\% DM) & 14.95 \\
Tannin (\% DM) & 0.543 \\
\hline
\end{tabular}


Journal of Agriculture and Food Sciences

Volume 19 Number 1, April 2021 pp 48- 62

Esiegwu, A. C. and Obih, T.K.O

Table 3: Performance indices of broiler starter birds offered dietary supplement of comfrey leaves extract

\begin{tabular}{lccllll}
\hline Parameters & \multicolumn{2}{c}{ Treatments } & & & & \\
& $\mathbf{T}_{\mathbf{1}}$ & $\mathbf{T}_{\mathbf{2}}$ & $\mathbf{T}_{\mathbf{3}}$ & $\mathbf{T}_{\mathbf{4}}$ & $\mathbf{T}_{\mathbf{5}}$ & SEM \\
\hline Mean initial weight (g) & 197.4 & 198 & 197.6 & 194.4 & 198.00 & 0.31 \\
Mean final weight (g) & 560.0 & 576 & 576 & 600 & 590 & 12.11 \\
Mean weight changes (g) & 362.6 & 378 & 378 & 402.6 & 392 & 8.10 \\
Mean daily weight gain (g) & 22.66 & 23.62 & 23.62 & 25.16 & 24.5 & 1.2 \\
Mean daily feed intake (g) & 54.48 & 65.79 & 57.37 & 53.07 & 54.85 & 5.1 \\
Feed conversion ratio & 2.40 & 2.78 & 2.42 & 2.11 & 2.24 & 0.2 \\
Cost/kg of feed & 120.21 & 140.11 & 123.11 & 124.01 & 125.11 & \\
Cost/kg weight gain & 288.50 & 389.51 & 297.93 & 261.66 & 280.25 & \\
\hline
\end{tabular}

Note: $\mathrm{T}_{1}=$ Control (Normal water, $0 \mathrm{ml} /$ litre of $\mathrm{H}_{2} 0$ ); $\mathrm{T}_{2}=$ conventional supplement (divertamin)

$\mathrm{T}_{3}=25 \mathrm{ml}$ extract/litre of $\mathrm{H}_{2} \mathrm{O} ; \mathrm{T}_{4}=50 \mathrm{ml}$ extract/litre of $\mathrm{H}_{2} \mathrm{O} ; \mathrm{T}_{5}=75 \mathrm{ml}$ extract/litre of $\mathrm{H}_{2} \mathrm{O}$

Table 4: Haematological indices of broiler starter birds offered dietary comfrey leaves extract

\begin{tabular}{lrrrrrl}
\hline Parameters & $\mathbf{T}_{\mathbf{1}}$ & \multicolumn{1}{c}{$\mathbf{T}_{\mathbf{2}}$} & \multicolumn{1}{c}{$\mathbf{T}_{\mathbf{3}}$} & \multicolumn{1}{c}{$\mathbf{T}_{\mathbf{4}}$} & \multicolumn{1}{c}{$\mathbf{T}_{\mathbf{5}}$} & $\mathbf{S E M}$ \\
\hline Haemoglobin (g/dl) & 11.70 & 11.10 & 11.40 & 10.80 & 11.10 & 0.40 \\
Packed cell volume (\%) & 36.00 & 34.00 & 32.00 & 32.00 & 34.00 & 2.01 \\
White blood cell (t) & 10.50 & 10.30 & 10.20 & 10.40 & 10.60 & 0.19 \\
Neutrophil (\%) & 52.00 & 55.00 & 53.00 & 58.00 & 52.00 & 2.5 \\
Eosinophil (\%) & 2.00 & 1.00 & 1.00 & 1.00 & 2.00 & 0.1 \\
Basophil (\%) & 0.00 & 0.00 & 0.00 & 0.00 & 0.00 & 0.0 \\
Lymphocytes (\%) & 45.00 & 43.00 & 44.00 & 40.00 & 45.00 & 2.1 \\
Monocytes (\%) & 1.00 & 1.00 & 2.00 & 1.00 & 1.00 & 0.1 \\
Red blood cell (X10 $\left.{ }^{12} / 1\right)$ & 11.20 & 11.00 & 11.00 & 10.90 & 11.00 & 0.17 \\
ESR (mm ${ }^{3} / 1^{\text {st }}$ hour) & 30.0 & 40.0 & 30.00 & 50.00 & 40.00 & 8.03 \\
MCV (fl) & 32.1 & 30.9 & 30.10 & 28.60 & 30.90 & 1.5 \\
MCH (Pq) & 10.4 & 10.1 & 10.20 & 9.60 & 10.10 & 0.05 \\
MCHC (g/dl) & 32.5 & 32.6 & 30.20 & 33.80 & 32.60 & 1.7 \\
\hline
\end{tabular}


Journal of Agriculture and Food Sciences

Esiegwu, A. C. and Obih, T.K.O.

Volume 19 Number 1, April 2021 pp 48-62

Table 5: Serum biochemical indices of broiler starter birds offered dietary comfrey leaves extract

\begin{tabular}{lllllll}
\hline Parameters & $\mathbf{T}_{\mathbf{1}}$ & $\mathbf{T}_{\mathbf{2}}$ & $\mathbf{T}_{\mathbf{3}}$ & $\mathbf{T}_{\mathbf{4}}$ & $\mathbf{T}_{\mathbf{5}}$ & SEM \\
\hline Urea $(\mathrm{mg} / 100 \mathrm{ml})$ & 5.8 & 5.6 & 5.4 & 5.5 & 5.2 & 0.3 \\
Creatinine (mg/100ml) & 62 & 60 & 58 & 60 & 56 & 3.01 \\
Cholesterol (mmol/l) & 66 & 6.0 & 5.2 & 6.2 & 6.4 & 0.91 \\
Total protein (mg/100ml) & 60 & 55 & 56 & 56 & 58 & 2.5 \\
Albumin (g/dl) & 20 & 20 & 18 & 20 & 18 & 1.3 \\
Globulin (g/dl) & 40 & 35 & 38 & 36 & 40 & 2.0 \\
Sodium (mmol/l) & 42 & 42 & 40 & 40 & 40 & 1.1 \\
Potassium (mmol/l) $_{\mathrm{HCO}^{-}(\mathrm{mmol} / \mathrm{l})}^{1.4}$ & 1.5 & 1.2 & 1.3 & 0.1 & 0.4 \\
$\mathrm{Cl}^{-}(\mathrm{mmol} / \mathrm{l})$ & 11.2 & 10.6 & 11.0 & 10.5 & 10.5 & 0.5 \\
ALK (iu/l) & 25 & 23 & 22 & 22 & 22 & 1.5 \\
SGOT (iu/l) & 1.2 & 1.3 & 1.2 & 1.3 & 1.2 & 0.1 \\
SGPT (iu/l) & 11.0 & 10.5 & 11.3 & 10.4 & 11.2 & 0.5 \\
\hline
\end{tabular}

